\title{
The Conception of Building an Independent Soul Citizen According to Ki Ageng Suryomentaram
}

\author{
S Ediyono \\ Universitas Sebelas Maret \\ Surakarta, Indonesia \\ ediyonosuryo@yahoo.com
}

F A Lazzavietamsi, A I Ito

STKIP PGRI Tulungagung

Tulungagung, Indonesia

fandyadpen@gmail.com, esuro25@gmail.com

\author{
W S Rondli \\ Universitas Muria Kudus \\ Kudus, Indonesia \\ wawan.shokib@umk.ac.id \\ Rafzan \\ Jambi University \\ Jambi, Indonesia \\ rafzan@student.upi.edu
}

\begin{abstract}
This study is to explore the concept of building an independent spirit of citizens according to $\mathrm{Ki}$ Ageng Suryomentaram through the book written by his pupil. The study used a qualitative philosophical approach with a factual historical design by implementing philosophical investigation following Ki Ageng Suryomentaram's ways and line of thought provided in the book entitled Ki Ageng Suryomentaram through interpretation, induction and deduction, internal coherence, holistic, idealization, comparison, heuristic, inclusion or analogical language, description, specific method and researchers' reflection. The result is the idea of an independent soul of citizen according to Ki Ageng Suryomentaram is when the citizens' thoughts, words, and deeds are based on the feeling of being free from the colonization, which is the essence of an independent soul. An independent soul is the basis and purpose of a just and civilized nation. Thus, this study can be used as a reference in the implementation of civic education in the content of love towards the nation. Moreover, the excavation of philosophical values contained in the teachings of $\mathrm{Ki}$ Ageng Suryomentaram can strengthen the values contained in the ideology of Pancasila.
\end{abstract}

Keywords - citizen; independent soul; Ki Ageng Suryomentaram

\section{INTRODUCTION}

The soul living inside of a human being is immaterial but has energy while the body, which is material, has none of it [1] Hence, the body is a manifestation of the soul [2]. The primary component of a nation is the inhabitants called the citizen. Thus, every national issue is majorly rooted from the citizen which means that a nation depends on how the citizen is [3]. Therefore, developing a citizen is a focal point in the life of a nation. In Indonesia, there is a paradigm exists around the public that says liberty is not freedom. Sukarno described liberty as there is no more exploitation of a nation to the other nations or humans who colonize other humans [4]. On the other hand, freedom is a more individualistic conception of life where the major concept is self-exploration [5]. In post-reform era, the spirit of freedom is more important than the spirit of liberty. Many people do not know or even praise the freedom that actually schakles people on complex partial issues. One of the most prominent figures in teaching liberty to the Indonesian is $\mathrm{Ki}$ Ageng Suryomentaraman who has inspired the founders of the nation and given birth to PETA soldiers which later became the forerunners of the TNI [6]. He was the man who had achieved a true meaning of liberty and shared it with the others. Ki Ageng Suryomentaraman's concept of a free soul becomes interesting to review and formulate since it might rebuild Indonesia into a high-civilized nation.

Various issues that emerged after the reform reaffirmed the question of whether Indonesia citizen is absolutely free or it is merely a false assumption. To answer the question, it is necessary to examine the issue of liberty of how the conception of a free soul actually is and how to build a free spirit of Indonesia citizen according to Ki Ageng Suryometaraman. Thus, it might lead to the formulation of the concept of building a free soul of Indonesian citizens according to $K i$ Ageng Suryomentaraman.

\section{METHOD}

This study uses a qualitative philosophical approach with historical factual research methods, data sources in this study obtained from research results, books, scientific articles that examine the thoughts of Ki Ageng Suryomentaraman. The primary data source is taken from the research that studied $\mathrm{Ki}$ Ageng Suryomentaraman, while the secondary source of books, magazines, and scientific articles that describes the thoughts of Ki Ageng Suryomentaraman. From the data, a philosophical investigation is conducted by following the way and the direction of thought presented in the book entitled $\mathrm{Ki}$ Ageng Suryomentaram through the process of interpretation, induction and deduction, internal coherence, holistic, historical continuity, idealization, comparative, heuristic, inclusive or analogical language, description, specific methods and reflection of private researchers. 


\section{RESULTS AND DISCUSSION}

Ki Ageng Suryomentaraman was the 55th child of 79 children of Sri Sultan Hamengkubuwono VII and born on the May $20^{\text {th }}$, 1892. Ki Ageng Suryomentaraman's life journey, or familiarly called KAS, has a similar life pattern with Sidahrta Gautama who was a prince who chose to live a modest life outside of his empire. His real name is Bendoro Raden Mas (BRM) Kudiarmadji and he was appointed as a prince named Bendoro Prince Haryo (BPH) Suryomentaram on his 18th [7]. Since KAS is a noble person, he obtained a sufficient amount of learning about religion and general knowledge. KH Ahmad Dahlan was his tutor in learning about religion. Various facilities and pleasures as a prince felt by KAS, but his mind was always worried since there was a question on his mind that he could not find the answer. Oftentimes, he did something that his parents forbade just to find the answer of a question filling his soul. Until one day, when his grandfather, who was also a Patih Danurejo VI (Prime Minister), died and his mother divorced by Hamengkubuwono VII also died, KAS felt restless and decided to escape from the palace [8]. KAS's anxiety was coming from his search to meet man [9]. Along in his life, KAS was always looking for the thing known as man. The search was preceded by the attitude that was not only involving actions but also repeated and deeper mind and heart reflection. The result of self-reflections and action done by KAS was to meet a real man that meant "a self has met me without any characters of me" which was by KAS called as kramadangsa which was a soul that served interests or purposes from human desire.

The meeting with man was understood by KAS when he met his second wife after 10 years being a widow. At one night, KAS awoke his wife and told her that he had met with a man figure he had been looking for. KAS saw this man when he plunged himself without doubt into a river. In the depths of the river, he could see his own self was afraid of being drowned and died. The 'self' was later called by KAS as a soul without a character, an eternal soul exists in every human being [10]. After finding the man he was always looking for, KAS always met his relatives and discussed about his experience, and he also tried to find the meaning of life in his live. Besides KAS tried to show anyone that they should meet with this self to be a free soul, a soul that is not tied up to the owner of the soul.

Ki Ageng Suyomentaraman explains the concept of the human soul through the concept of soul kramadangsa which is the "I" soul in human self that has existed since the human being born and dominates the human life [11]. The "I" is formed from the records and the sense of life stored in man from birth to the end of life. The "I" exists in the human being lies in the third dimension that supports the second and first dimensions namely various human notes and feelings [6]. The detail is captured in the following fig. 1.

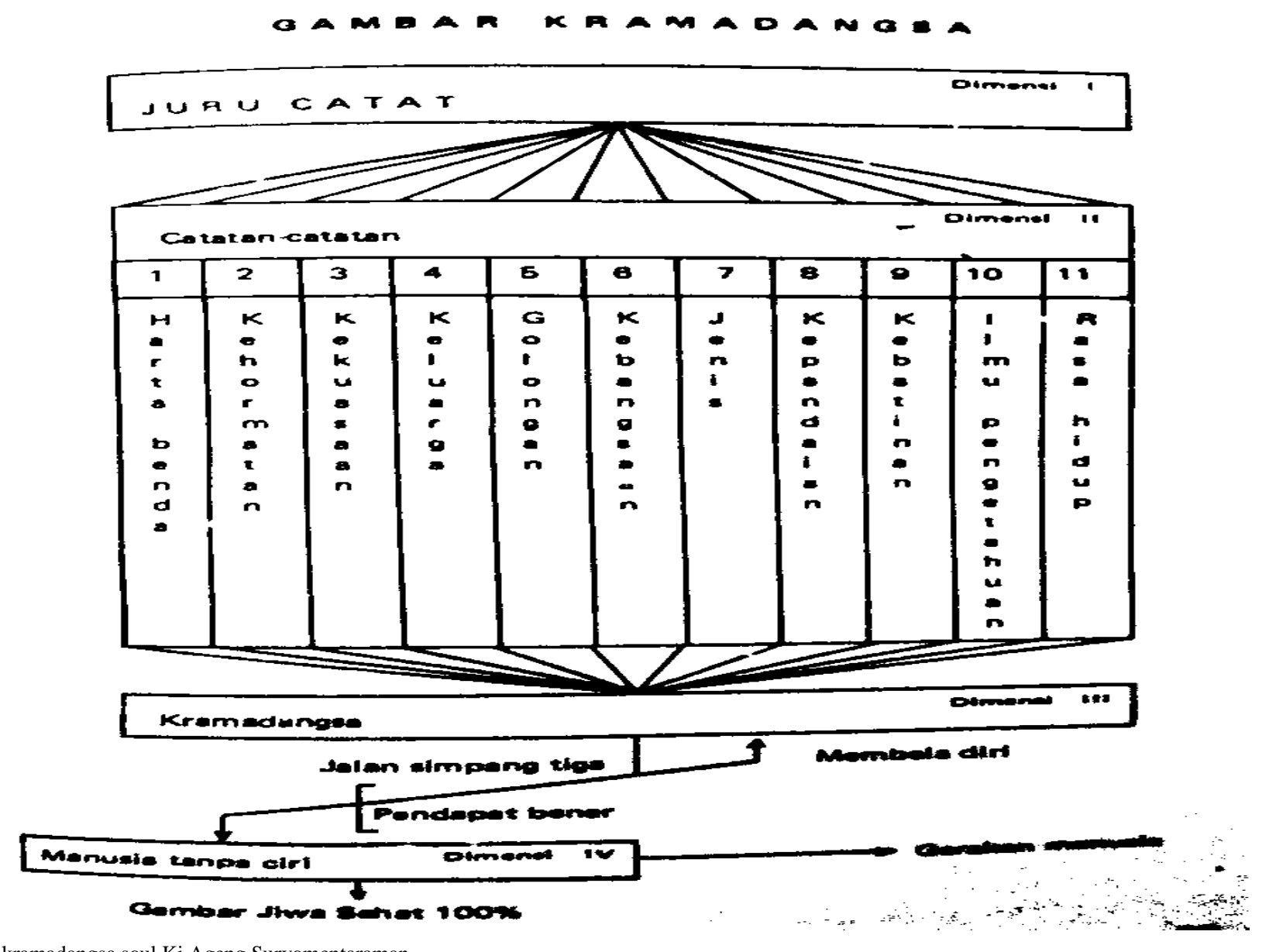

Fig. 1. A kramadangsa soul Ki Ageng Suryomentaraman 
The 'Juru Catat' of the first dimension is the element of human knowledge gained from birth to the end of human life, while in the second dimension is the sense of human being perceived by CAS from experiences during the search for a human figure consisting of property, honor, power, family, nationality, kind, intelligence, soul, science, and sense of life. The third dimension is called by KAS as kramadangsa soul which means a soul that has a name indicating an individual peculiarities, a soul that has a name [6]. A kramadangsa soul often feels confused because it has to serve 11 human feelings that exist in the second dimension. As exemplified by KAS, when a human feels anger must choose between to hold or express his anger. Yet, either holding or expressing anger is actually still an anger, it is still the same "I" that has a name and character. However, the kramadangsa soul is actually always communicating with the human spirit that has characteristic found in all humans. When the silent person does not express anger and restrain his anger but can see the his angry self, that person is actually in the human soul which has no character and it is called as a true soul. This characterless soul is a free and happy soul which is not bound by anything.

KAS explained that to build a good citizen then understanding the true meaning of a nation and citizens is the initial process. Moreover, to build it, the primary object that should be taught is the soul and then the body. It seems it is also confirmed by the Indonesia Raya song where there is a phrase says "....Bangunlah jiwanya, bangunlah badannya...." [12]. Accordingly, to build the body one must first build his soul, including in building the citizens. Building the soul of a citizen is always asserted by CAS through the sense of "I own the country". The feeling of belonging might be trivial but is something that is very important in the life of a nation [13]. However, at the present time, this matter has not received any special attention but become worse even more since the Indonesia independence day in 1945. The concept of an independent soul citizen cannot be placed on individual viewpoint since independence itself is actually based on the value of human collectivity in the process of living together. In consequence, the collectivity of being freed from the colonization by other nations has always been the principal basis of an independent nation [6]. KAS even illustrated the pain of being restricted in much way since they were colonized by other nations in the Dutch era. Yet, it is ironic. While previously the colonists faced by the Indonesian were other nations, now the colonist is their own kind with the foreign nations controlling them.

The challenge of building a sense of "I own the country" is getting heavier now but it should be the main instrument of the government in growing it in every Indonesian through a planned development program. KAS states that building and preserving an independent soul citizen is through education. But the education must be in accordance with the educational principles of Ki Hadjar Dewantara which is educating the nature of nature, nationality, independence, culture, and humanity [14]. KAS is one of the initiators of Taman Siswa establishment and was a teacher for the adults. This is why his middle name is Ageng which means a teacher for adults. Independence is something that must be maintained and citizens are the main defense in maintaining the resilience of a country [15]. Every Indonesia citizen is responsible for guarding his country [16], especially now, people could be easily provoked by third parties to fight and tend to forget that independence should be maintained.

Religious institutions and informal religious teachings that maintain Pancasila are the most influential factors in the mental and spiritual development of citizens, since, in ancient times, KAS often shared his knowledge of kramadangsa souls in a recitation. The understanding of kramadangsa made by KAS is an interpretation of a spiritual journey to the origin of the human being [11]. In which, it is actually the idea is contained in every religion and is the core of every religion. The citizens have complicated components and to this day, there are still many questions that cannot be understood by reason related to the components of human body [17]. The Javanese tradition as taught by KAS actually directs every human being on the journey to understand the real concept of life and death, the concept of being and non-being.

The current aspect of education is too rigid and formal, all of which rely on materialistic ideas, until the point that education forgets that the object of education is human beings which are not things or substances that have different characteristics that generalization and uniformity will be impossible [18]. For that, the main strategy in building an independent soul citizen is through religious institutions and recitations that always maintain the values of Pancasila as the foundation of a nation. The correlation between the government, religious institutions, and citizen is illustrated in fig. 2.

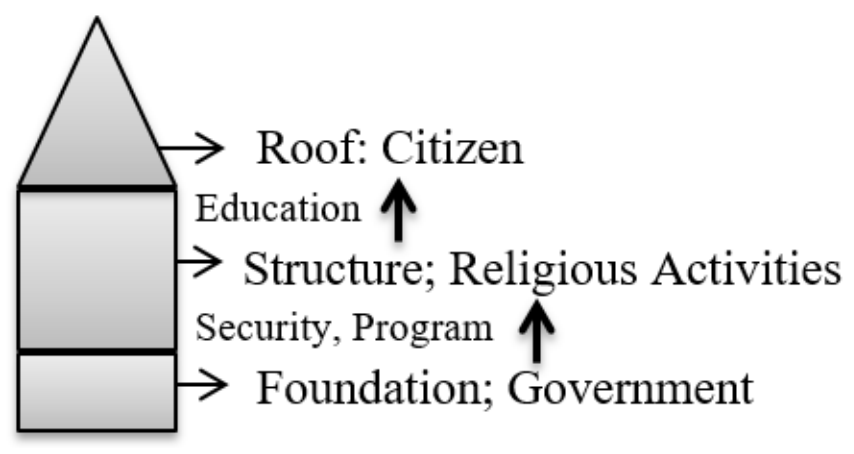

Fig. 2. The correlation between the government, religious institutions, and citizen.

\section{CONCLUSION}

The conception of building independent soul citizens is the foundation of love of the homeland and the nation of Indonesia. No matter how strong a country is when the soul of a citizen is weak then at any moment, a country might collapse. Thereof, the real power of a nation lies in its citizen and the power of the citizen lies in the soul of the citizen. Building a nation means building the soul of the citizen. To build the soul of a citizen must first understand the independent soul citizen and then perform the knowledge. The understanding should be led and exemplified by the government and religious teachers in the informal sector. Pastors, Kyai, Monks, and other religious leaders have a very important in building a citizen with an independent soul. The government can support the 
religious activities through programs, security, and socialization that always call for maintaining Pancasila as the basis of the nation.

\section{REFERENCES}

[1] V. Karasmanis, "Soul and body in Plato," Int. Congr. Ser., vol. 1286, pp. $1-6,2006$.

[2] S. Broadie, "Soul and body in Plato and Descartes," Proc. Aristot. Soc., 2001.

[3] E. F. Isin and B. S. Turner, "Investigating citizenship: An agenda for citizenship studies," Citizensh. Stud., 2007.

[4] W. Silaban, "Pemikiran Soekarno Tentang Nasionalisme," J. Din. Polit., vol. 1, no. 3, pp. 1-6, 2012.

[5] J. Miletzki and N. Broten, Development as freedom. 2017.

[6] K. A. Suryomentaraman, Ajaran-Ajaran Ki Ageng Suryomentaraman Jilid 2, 1st ed. Jakarta: Idayu Press, 1985.

[7] N. Prihartanti, Kepribadian Sehat Menurut Suryomentaram. 2003.

[8] K. A. Suryomentaraman, Ajaran-Ajaran Ki Ageng Suryomentaraman jilid 3, 1st ed. Jakarta: Idayu Press, 1985.

[9] Y. Ade Saputra, "Filsafat Manusia Telaah Kritis Atas Pemikiran Ki Ageng Suryomentaraman,” UIN Sunan Kalijaga Yogyakarta, 2017.

[10] Nikmaturrohmah, "Konsep Manusia Ki Ageng Suryomentaram Relevansi dengan Pembentukan Karakter Sufistik," UIN Walisongo Semarang, 2016.

[11] S. Endraswara, Ilmu Jiwa Jawa; Estetika dan Citarasa Jiwa Jawa, 1st ed. yogyakarta: Narasi, 2012.

[12] wage rudolf supratman, "Indonesia Raya - Wikipedia bahasa Indonesia, ensiklopedia bebas," wikipedia.

[13] V. Bader, "For Love of Country," Political Theory. 1999.

[14] K. H. Dewantara, Ki Hadjar Dewantara; Pemikiran, Konsepsi, Keteladanan, Sikap Merdeka, 5th ed. yogyakarta: UST Pers dan Majelis Luhur Taman Siswa, 2013.

[15] A. Keating, "Educating Europe's citizens: Moving from national to postnational models of educating for European citizenship," Citizensh. Stud., 2009.

[16] The Republic of Indonesia, "Undang-Undang Dasar Negara Republik Indonesia Tahun 1945," Statute, pp. 1-9, 1945.

[17] A. Vrahimis, Meditations on first philosophy. 2017.

[18] Marzuki, "Politik Pendidikan Nasional dalam Bingkai Undang-undang Sistem Pendidikan Nasional," J. Penelit. Hum., vol. 17, no. 2, pp. 16-38, 2012 . 